\title{
Utilization of Oak (Quercus petreae (Matt.) Liebl.) Bark for Anaerobic Digested Biogas Production
}

\author{
Ádám Nándor MAKK ${ }^{\mathrm{a} *}$ - Tamás RÉTFALVI ${ }^{\mathrm{a}}$ - Tamás HoFMANN ${ }^{\mathrm{a}}$ \\ ${ }^{a}$ Institute of Chemistry, University of Sopron, Sopron, Hungary
}

\begin{abstract}
Fossil fuel depletion has led to an increasing number of research studies and applications focusing on renewable energy, such as different types of biomass. Lignocellulosic biomass represents an abundant source of biomass suitable for energy production in various forms. The present research investigates the application possibility of pedunculate oak bark (Quercus petrea (Matt.) Liebl.) for the production of biogas via anaerobic digestion. This research has significant novelty, as only a few examples on the utilization of tree bark wastes for the production of biogas can be found in the scientific literature. One of the key factors of increasing biogas yield is the efficient hydrolysis of the basic material, which is achieved by different pretreatment methods. In this study, oak bark was pretreated by microwave energy, by extraction, and by the combination of these two methods. The semi-continuous thermophylic anaerobic digestion of untreated oak bark resulted a $76.3 \mathrm{ml} / \mathrm{g}$ volatile solid specific methane yield over a 50-day period, which was not significantly lower than methane yield gained from pretreated basic material. Results indicated that oak bark is suitable for the production of biogas even without the application of the investigated pretreatment techniques. As extraction of oak bark does not impair biogas production, the complex biorefinery utilization of oak bark in the form of extraction bark polyphenols and the subsequent anaerobic fermentation of lignocellulosic residue can be accomplished in the future.
\end{abstract}

lignocelluloses / biorefinery / forestry by-products / renewable energies

Kivonat-A kocsánytalan tölgy (Quercus petreae (Matt.) Liebl.) kéreg alkalmazhatósága anaerob úton előállítható biogáz termelés céljára. A fosszilis energiahordozók kimerülése miatt számos alkalmazási terület és kutatás összpontosít a megújuló energiaforrásokra. A lignocellulózok, mint biomassza alapú energiahordozók kutatása releváns téma, mivel nagy mennyiségben állnak rendelkezésre. Ezen kutatás a kocsánytalan tölgy (Quercus petreae (Matt.) Liebl.) kéreg alkalmazási lehetőségeit vizsgálja az anaerob úton előállítható biogáz termelés céljára. A kéreg hulladék effajta felhasználásával foglalkozó szakirodalmak száma szegényes. A lignocellulózok esetében kulcs fontosságú eljárás az alapanyag hidrolízise a biogázhozam, ezzel együtt a metánhozam növelése érdekében. A tölgy kéreg alapanyag előkezelése mikrohullámmal, extrakcióval és együttes alkalmazásukkal történt. A kezeletlen tölgy kéreg 50 napos, félfolyamatos, termofil anaerob fermentáció során $76.3 \mathrm{ml} / \mathrm{g}$ szerves szárazanyag fajlagos metánhozam érhető el, ami szignifikánsan nem alacsonyabb a kezelthez képest. Az eredmények alapján a tölgy kéreg, alkalmas metán előállításra előkezelési eljárások nélkül is. Mivel a kéreg extrakciója nem rontja a biogáz termelés hatékonyságát, ezért a kéreg melléktermék komplex kémiai hasznosítása, az extrakt anyagok kivonása valamint a visszamaradt lignocellulóz vázanyag anaerob fermentációja által a jövőben lehetséges.

\section{lignocellulózok / biofinomítás / erdészeti melléktermékek / megújuló energia}

\footnotetext{
* Corresponding author: makkadamnandor@gmail.com; H-9400 SOPRON, Bajcsy-Zs. u. 4, Hungary
} 


\section{INTRODUCTION}

As industrialization and motorization increased, the world began to depend on fossil fuels, especially petroleum-based fuels (Nigam - Singh 2010). Today, fossil fuels make up $80 \%$ of the primary energy consumed in the world (Escober et al. 2009). The burning of fossil fuels causes much environmental damage and adds to global warming (Nigam - Singh 2010, Monlau et al. 2014). In this respect, the development and application of alternative and renewable energy sources - especially the second-generation resources, mainly lignocellulosic biomass - has become a global focus today.

There are many forms of the energetic utilization of lignocellulosic materials including the production of biogas, bioethanol, biodiesel, etc. The present study focuses on the production of biogas by anaerobic digestion. The anaerobic digestion process comprises four steps: hydrolysis, acidogenesis, acetogenesis, and methanogenesis. During this process, the lignocellulosic biomass is transformed into biogas (Monlau et al. 2014); this has several benefits when compared the biogas produced from other forms of waste materials. A lesser amount of biomass sludge and the minimal odour emission are two main advantages (Smeth et al. 1999) as well as its compliance with many waste strategies (Ward et al. 2008). The energetic balance of the biogas is the most effective among the other biomass-based energy sources as the output (the energy yield from the biomass) and the input (the assigned primary energy) ratio is $28 \mathrm{MJ} / \mathrm{MJ}$ (Deublein - Steinhauser 2008).

According to the research of Brown et al. (2012), when comparing the methane yield of the anaerobic fermentation of various lignocellulosic materials, the best results were achieved for corn stover $(124 \mathrm{ml} / \mathrm{g} \mathrm{VS})$ and wheat straw $(139.1 \mathrm{ml} / \mathrm{g} \mathrm{VS})$ where VS stands for volatile solid. The exceptional methane yields from wheat straw and corn stover were also confirmed by Liew et al. (2012). These two basic materials are, in fact, the most commonly and successfully used lignocellulosic biomass for anaerobic fermentation to our days.

Lignocellulosic biomass is composed of three structural polymers, namely cellulose, hemicelluloses, and lignin, which are interconnected with each other by primary and secondary chemical bonds (Fengel - Wegener 1984). In order to produce biogas from lignocelluloses, structural polymers (primarily cellulose and hemicelluloses) have to be converted into monomeric sugars (Chandra et al. 2012) to enable efficient fermentation. Accordingly, the biogas production process is divided into three phases: pretreatment of the basic material, anaerobic-hydrolysis/methane production, and post-treatment of the liquid fraction.

The pretreatment of the basic material can improve the hydrolysis of structural polymers and increase the total biogas yield in the case of the lignocelluloses (Hendriks - Zeeman 2009). Pretreatments involve physical (e.g. grinding, heat treatment, microwave treatment), chemical (e.g. weak acidic hydrolysis using dilute $\mathrm{HCl}, \mathrm{H}_{2} \mathrm{SO}_{4}, \mathrm{CH}_{3} \mathrm{COOH}$, alkaline hydrolyis by $\mathrm{NaOH}$ or $\mathrm{Ca}(\mathrm{OH})_{2}$, solvent extraction, ozonolysis, etc.), combined physicalchemical (steam explosion, fiber explosion using $\mathrm{NH}_{3}$ or $\mathrm{CO}_{2}$, cavitation, microwave + chemical treatment) and biological pretreatments (using fungi or enzyme preparations). Through the combined application of different methods, pretreatment efficiency can be increased significantly (Sun - Cheng 2002, Taherzadeh - Karimi 2008).

Patil et al. (2016) reported on the twofold methane yield increase as an effect of combined physical-chemical pretreatment (alkaline-hydrodynamic cavitation) of wheat straw basic material. Song et al. (2014) investigated the effect of various acidic and alkaline pretreatments of wheat straw on the methane yield. According to their results, yield was improved from $100.6 \mathrm{ml} / \mathrm{g}$ VS (from untreated basic material) to $216.7 \mathrm{ml} / \mathrm{g} \mathrm{VS}$ (optimum pretreated basic material). 
As opposed to wheat straw and corn stover, only a few examples can be found in the scientific literature on the application possibilities of woody lignocellulosic wastes and byproducts for anaerobic fermentation purposes. These examples involve willow shoots (Horn et al. 2011), pine bark (Salehian - Karimi 2013), and yard trimmings (Zhao et al. 2014).

Wood bark is a large volume by-product generated during the processing of wood logs (Molnár 2004). The most important wood logging species in Hungary are oak, black locust, and poplar, all of which have an especially high bark ratio. Data on logged volumes in Hungary are presented in Table 1.

Table 1. Most important wood species in Hungary in terms of logged volume based on data from 2015 (KSH 2015)

\begin{tabular}{lc}
\hline Species (group) & $\mathbf{1 0 0 0 \mathbf { ~ m } ^ { \mathbf { 3 } }}$ \\
\hline Oak (Quercus spp.) & 1756 \\
Black locust (Robinia pseudoacacia L.) & 1488 \\
Poplar (Populus spp.) & 1329 \\
Sum & 4573 \\
\hline
\end{tabular}

According to Table 1., the species group with the highest logged volume in Hungary is oak (Quercus spp., including pedunculate-, sessile-, and Turkey oak). Bark thickness depends on species, age, and ecological parameters. On average, bark volume is about $5-24 \%$ of the total volume the trunk. In the case of oak, it is about 15-25\% (Molnár 2004). According to Table 1., about $229,000-1,098,000 \mathrm{~m}^{3}$ of bark waste are generated annually on average in Hungary from the logging and processing of oak, poplar and black locust. From this amount, oak bark wastes represent $260,000-439,000 \mathrm{~m}^{3}$ annually.

The present research focuses on the application possibilities of pedunculate oak bark (Quercus petreae (Matt.) Liebl., hereinafter: oak) for biogas production purposes. To the best of our knowledge, the use of oak bark material for biogas production has not been investigated yet. Pretreatment of the basic material was done using microwave energy and solvent extraction as well as by the combinaton of these two methods. The key questions of the research focus on whether there is a significant effect of the investigated pretreatment methods on methane yield, and whether oak bark without pretreatment can also be used for anaerobic biogas production. Results were compared with yields obtained from other lignocellulosic materials.

\section{MATERIALS AND METHODS}

\subsection{Sample materials}

Oak bark (5-6 kg) was collected from trunks of different trees growing in a mixed oak stand near the village of Harka (Hungary). The bark was processed immediatelly after collection in the following manner: bark was chopped into $\sim 2 \mathrm{~cm}$ long pieces using a Scheppach Basato 1 type band saw (Scheppach $\mathrm{GmbH}$, Ichenhausen, Germany) and ground using a Retsch SK3 type hammer mill (Retsch $\mathrm{GmbH}$, Haan, Germany) equipped with a sieve (mesh size $<4 \mathrm{~mm}$ ). The ground basic material was stored at $-18^{\circ} \mathrm{C}$ until pretreatment. 


\subsection{Pretreatment methods}

Extraction pretreatment: extraction was performed in order to remove such low molecular weight extractives (mainly polyphenols) that could act as inhibitors during the fermentation process. $100 \mathrm{~g}$ bark portions were extracted with $800 \mathrm{ml}$ distilled water for $24 \mathrm{~h}$ at room conditions. After extraction, the solution was discarded and the particles were dried at room temperature and stored at $-18{ }^{\circ} \mathrm{C}$ until use.

Microwave pretreatment: $250 \mathrm{~g}$ bark portions were treated with 700 Watt microwave energy in a household microwave oven for 2 x 2 min (Jackowiak et al. 2011, Makk et al. 2013). Treated bark was collected and stored at $-18{ }^{\circ} \mathrm{C}$ until use.

Combined pretreatment: bark was first microwave-treated then it was extracted with the methods described above. Treated bark was dried at room temperature and stored at $-18{ }^{\circ} \mathrm{C}$ until use.

The conditions of pretreatments are summarized in Table 2.

Table 2. Pretreatment methods and conditions

\begin{tabular}{llc}
\hline Sample & Pretreatment & Tag \\
\hline Control oak bark & - & $\mathbf{C}$ \\
Oak bark pretreated with microvave & microwave $(700 \mathrm{~W}, 2 \times 2 \mathrm{~min})$ & $\mathbf{M}$ \\
Oak bark pretreated with extraction & extraction (distilled water) & $\mathbf{X}$ \\
Combined pretreatment & microwave and extraction & $\mathbf{M}-\mathbf{X}$ \\
\hline
\end{tabular}

\subsection{Biogas production}

The production of biogas was carried out in a $2500 \mathrm{ml}$ volume brown bottle with thread neck (Merck KGgaA, Darmstadt, Germany) in a thermophilic $\left(55^{\circ} \mathrm{C}\right)$ environment (Memmert WNB 14 Basic water bath, Memmert GmbH, Schwabach, Germany). Biogas slugde occupied about $1000 \mathrm{ml}$ from the total volume of the bottle. Graft material for the fermentation experiments was obtained from the biogas plant of the Magyar Cukor Zrt., Kaposvár (Hungary) and was specialized to the fermentation of plant biomass. The introduction of the subtrate into the reactor as well as the measurement of the biogas yield was carried out daily. The anaerobic digestion experiments were run for 50 days. Produced gas was collected into Tedlar® bags. Measurement of the gas volumes was carried out using a $500 \mathrm{ml}$ Hamilton syringe (Sigma-Aldrich Kft, Budapest, Hungary).

The composition of the biogas was monitored using an Ecoprobe 5-IR type equipment (RS-Dynamics s.r.o., Prague, Czech Republic) calibrated for $\mathrm{CH}_{4}, \mathrm{CO}_{2}$ and $\mathrm{O}_{2}$ compounds. Calibration gas mixture comprised of $60 \%$ methane (v/v), 30\% $\mathrm{CO}_{2}(\mathrm{v} / \mathrm{v})$ and $10 \% \mathrm{O}_{2}(\mathrm{v} / \mathrm{v})$ and had a purity of $99.995 \%(\mathrm{v} / \mathrm{v})$. The proportion of the compounds in biogas samples was indicated in $\%(\mathrm{v} / \mathrm{v})$.

\section{RESULTS AND DISCUSSION}

Anaerobic fermentation of untreated oak bark material (labelled with „C" in the following tables and figures) yielded $76.3 \pm 2.5 \mathrm{ml}$ methane/g VS based on a 50-day average production. According to Salehian - Karimi (2013), the mesophilic anaerobic digestion of pine bark yielded $33 \mathrm{ml}$ methane/g VS, which could be improved up to $107 \mathrm{ml}$ methane/g VS by the pretreatment of the basic material. Zhao et al. (2014) studied the methane production of yard trimmings pretreated by various methods. The digestion of untreated basic material resulted in a methane yield of $17.6 \mathrm{ml} / \mathrm{g}$ VS and topped with $44.6 \mathrm{ml} / \mathrm{g}$ VS with the best pretreatment method. Horn et al. (2011) investigated the methane production from willow 
shoots and the possibilities of physicochemical pretreatments to obtain improved yields. Untreated basic material resulted in $200 \mathrm{ml}$ biogas $/ \mathrm{g} \mathrm{VS}$, while the digestion of the optimum pretreated material yielded $440 \mathrm{ml}$ biogas $/ \mathrm{g}$ VS with $52.4-54.3 \%(\mathrm{v} / \mathrm{v})$ methane contents related to the total volume of the produced biogas. According to the presented data, the methane yield of the anaerobic fermentation of untreated oak bark can be regarded as average, yet it is promising in respect to being a woody lignocellulosic material and an abundant forestry/wood industrial by-product. In the next steps, the effect of pretreatments (physical and chemical) was invesigated to assess if these pretreatments had a positive or negative effect on the overall methane yield.

\subsection{Microwave pretreatment}

Figure 1. summarizes the results on the fermentation of oak bark material pretreated with microwave radiation.

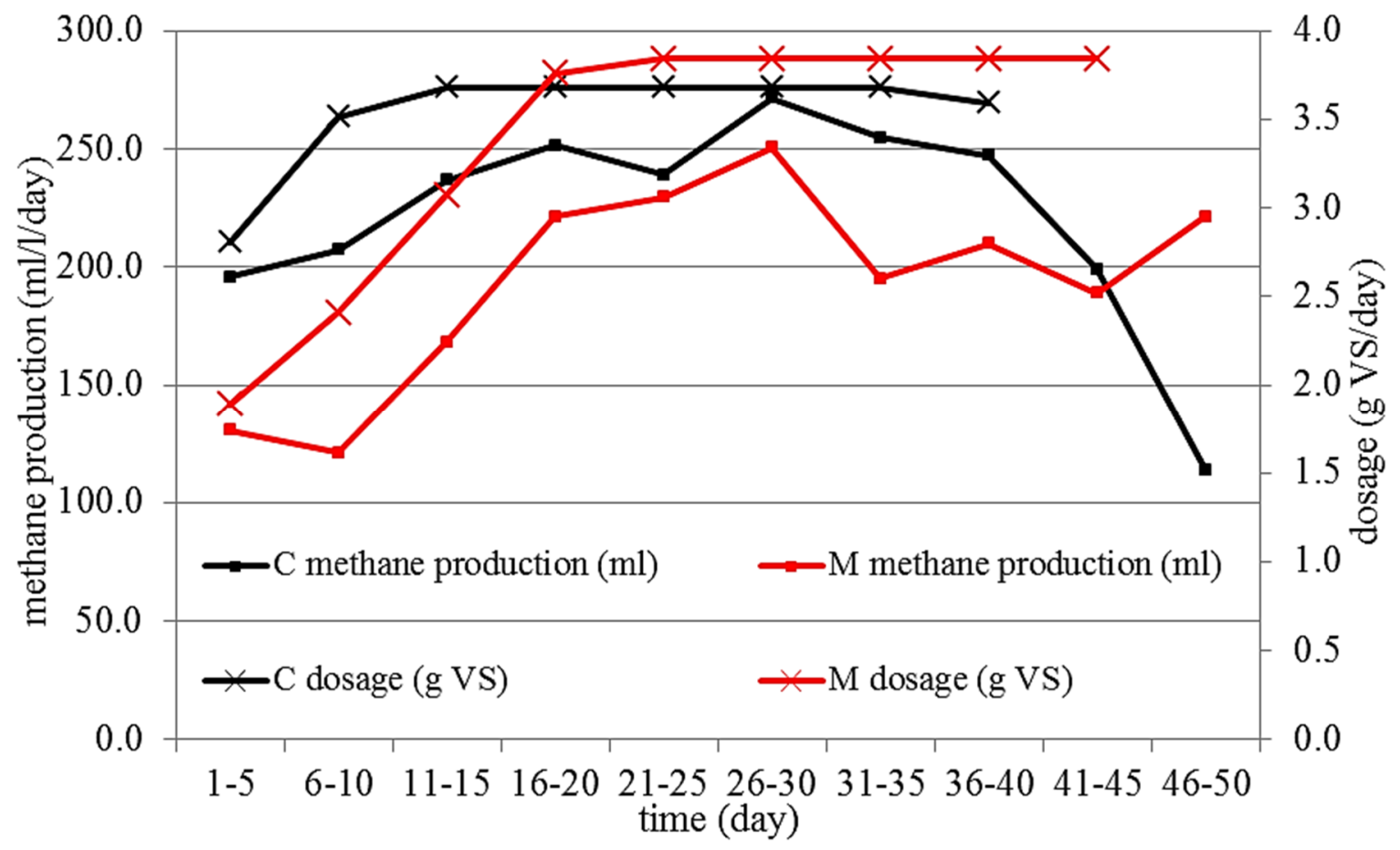

Figure 1. Methane production from oak bark and from oak bark pretreated with microwave energy. The time (day) indicates 5-day averages of methane production and dosage.

Substrates: C: untreated oak bark, M: oak bark pretreated with microwave energy.

Figure 1. clearly shows that stopping the introduction of the microwave-pretreated substrate into the reactor (at days 41-45) did not result in an immediate or subsequent decrease of methane yield. Microwave pretreatment dries the basic material significantly, which can result in the accumulation of organic material in the reactor by the thickening of the sludge. Lower water contents hinder fermentation reactions significantly causing lower yields and a delayed response.

Gas yields based on a 50-day average are summarized in Table 3. Values for pretreated material $(63.8 \pm 4.1 \mathrm{ml} / \mathrm{g}$ VS$)$ were significantly lower compared to that of the control material $(76.3 \pm 2.5 \mathrm{ml} / \mathrm{g}$ VS). One explanation of the lower methane production using pretreated basic material is the already mentioned thickening effect of the sludge caused by lowering water content in the reactor. The other explanation of the effect is that such cleavage and decomposition products are formed during microwave pretreatment of the basic material, 
which could have an inhibitory effect on methane production. Yet, investigations to prove this assumption have not been carried out in the present research.

Table 3. Methane production using untreated $(C)$ and microwave pretreated $(M)$ oak bark substrate (50-day averages, $n=50)$

\begin{tabular}{llrr}
\hline & & \multicolumn{1}{c}{$\mathbf{C}$} & M \\
\cline { 2 - 3 } Methane production & (ml/l/50 days) & 11083.9 & 9683.1 \\
$\Sigma$ added dry volatile solid & (g VS) & 145.3 & 151.7 \\
Average methane yield & (ml/g VS) & $\mathbf{7 6 . 3} \pm \mathbf{2 . 5}$ & $\mathbf{6 3 . 8} \pm \mathbf{4 . 1}$ \\
\hline
\end{tabular}

Results are indicated as average $\pm 95 \%$ confidence interval.

\subsection{Extraction pretretment}

The aim of the extraction of oak bark basic material was to remove compounds that could have possible inhibitory effects on fermentation and methane production. Extraction was done using distilled water as described in section 2.2. The time course of substrate dosage and of the methane production during the 50-day fermentation process is depicted in Figure 2.

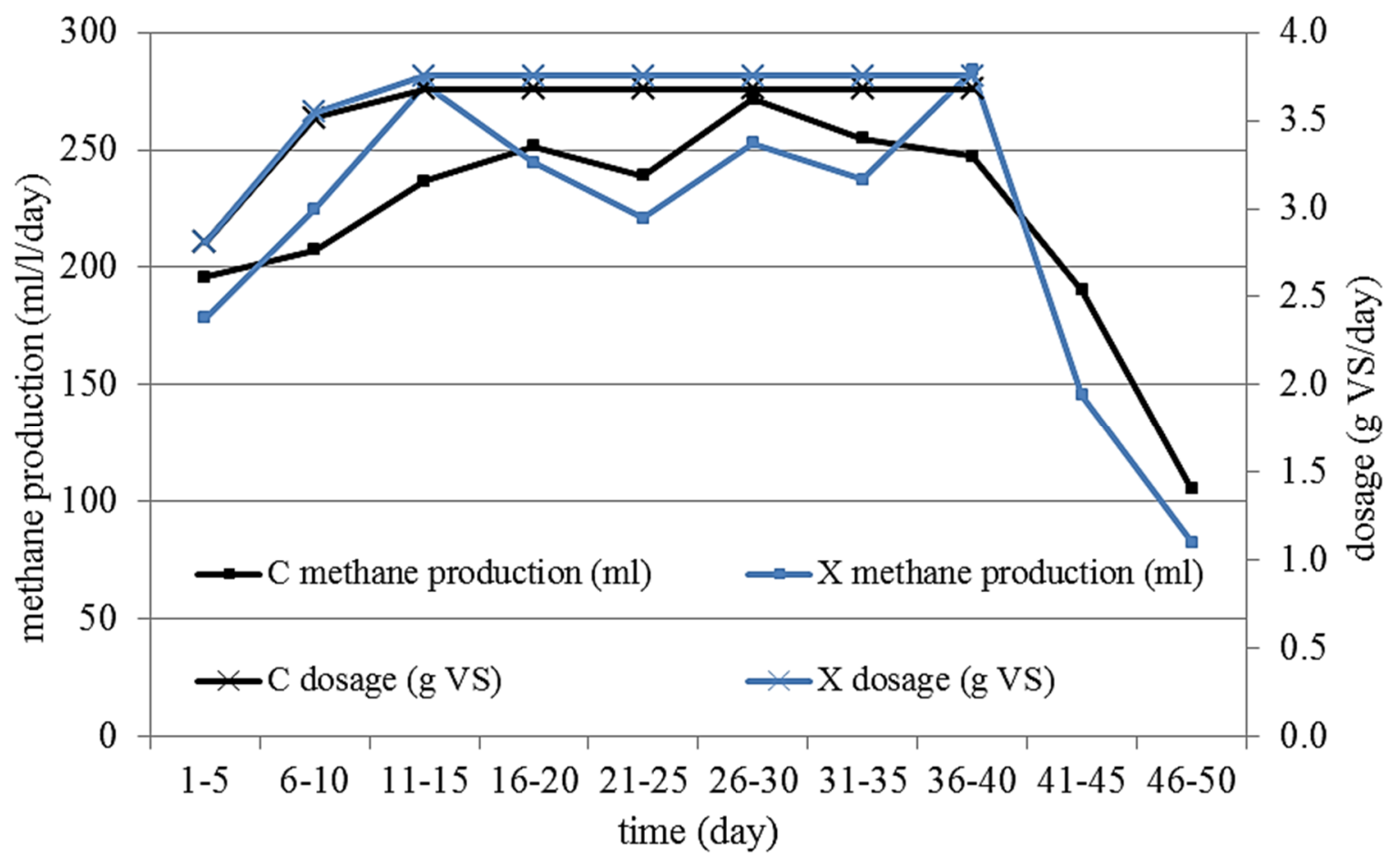

Figure 2. Methane production from oak bark and from oak bark pretreated with extraction The time (day) indicates 5-day averages of methane production and dosage.

Substrates: C: untreated oak bark, X: oak bark pretreated with extraction.

According to Figure 2., there is an increase in methane yield by the increase of the substrate. From these results, it was concluded that introduced organic matter was decomposed and accumulation of fermentable subtstrate was not significant, as opposed to microwave-pretreated bark (Figure 1.). According to Table 4., the aqueous pretreatment did not result in any significant positive effect on 50-day average methane yield $(72.9 \pm 5.4 \mathrm{ml} / \mathrm{g} \mathrm{VS})$, compared to the yield produced from control substrate $(76.3 \pm 2.5 \mathrm{ml} / \mathrm{g} \mathrm{VS})$. As methane yield did not increase after extraction, it was concluded that there are no compounds present in oak bark basic material, which have an inhibitory effect on 
the fementation process. As extraction had no significant negative effect on methane yield (the same volume of methane is produced with and without extracting the oak bark basic material), the complex biorefinery utilization and valorization of oak bark as an abundant byproduct can be accomplished by extraction (and utilization of extractives) and subsequent anaerobic fermentation of the residual bark to biogas.

Table 4. Methane production using untreated $(C)$ and extraction pretreated $(X)$ oak bark substrate (50-day averages, $n=50$ )

\begin{tabular}{llrr}
\hline & & \multicolumn{1}{c}{ C } & \multicolumn{1}{c}{ X } \\
\cline { 2 - 3 } Methane production & (ml/1/50 days) & 11083.9 & 10802.9 \\
$\Sigma$ added dry volatile solid & (g VS) & 145.3 & 148.2 \\
Average methane yield & (ml/g VS) & $\mathbf{7 6 . 3} \pm \mathbf{2 . 5}$ & $\mathbf{7 2 . 9} \pm \mathbf{5 . 4}$ \\
\hline
\end{tabular}

Results are indicated as average $\pm 95 \%$ confidence interval.

\subsection{Combined microwave and extraction pretreatment}

According to Taherzadeh - Karimi (2008), the combined pretreatment of lignocellulosic materials with microwave energy and the subsequent extraction results in a significantly improved biogas yield during anaerobic fermentation. The combined pretreatment was done on oak bark basic material and the results of methane production are depicted in Figure 3.

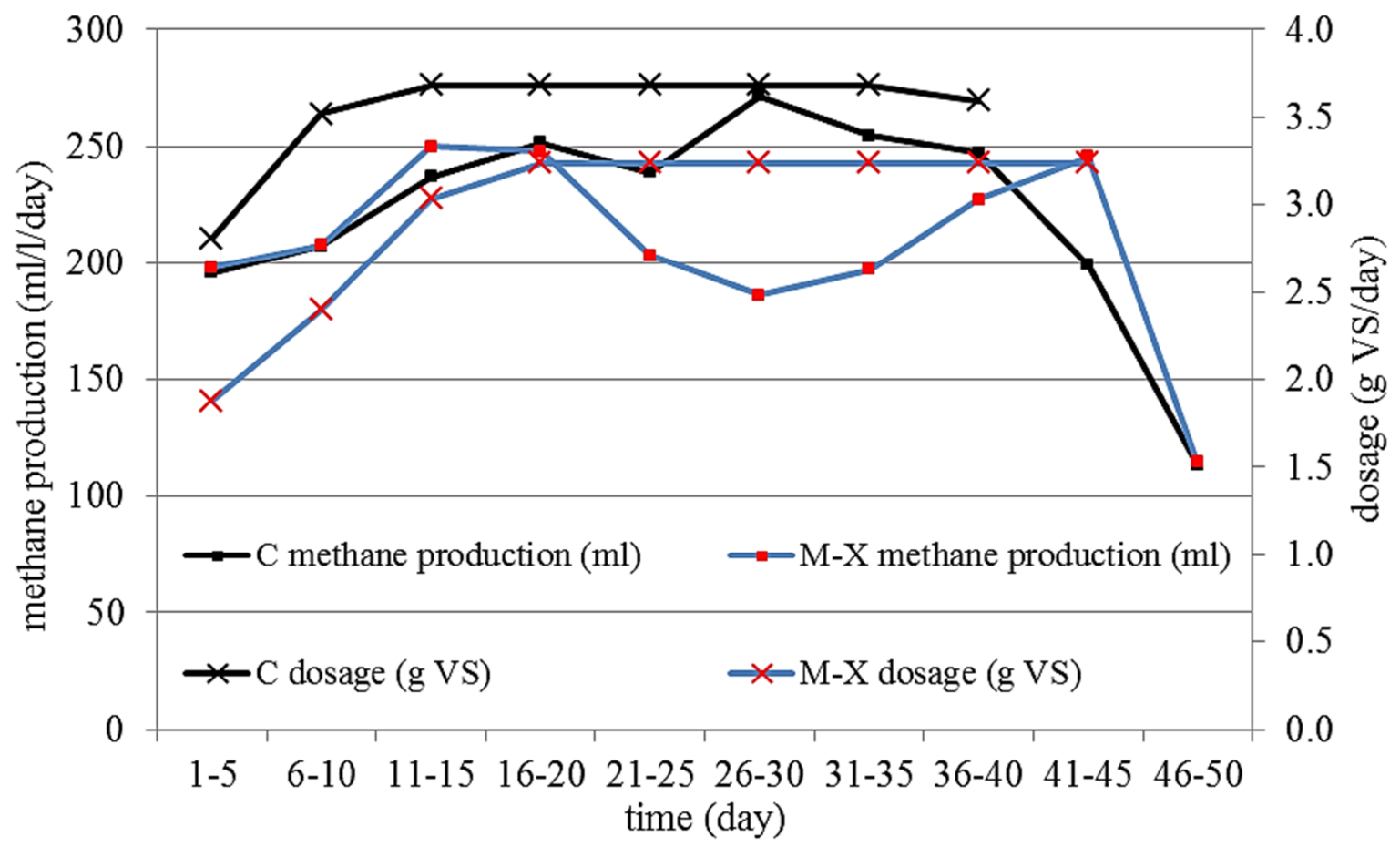

Figure 3. Methane production from oak bark and from oak bark pretreated with microwave energy and subsequent aqueous extraction. The time (day) indicates 5-day-averages of methane production and dosage. Substrates: $C$ : untreated oak bark, $M-X$ : oak bark pretreated with microwave energy and extraction.

According to Figure 3., stopping the feeding of both control and microwave-pretreated substrate into the reactor (at days 36-40 and days 41-45 respectively) resulted in an almost immediate decrease in the methane yield, similarly to extracted basic material (see Section 
3.2). Average methane yield did not differ significantly when using treated $(77.7 \pm 6.9 \mathrm{ml} / \mathrm{g} \mathrm{VS})$ and untreated $(76.3 \pm 2.5 \mathrm{ml} / \mathrm{g} \mathrm{VS})$ substrate for the fermentation (Table 5.).

Table 5. Methane production using untreated $(C)$ and microwave energy/extraction pretreated $(M-X)$ oak bark substrate (50-day averages, $n=50)$

\begin{tabular}{llcc}
\hline & & $\mathbf{C}$ & M-X \\
\cline { 3 - 4 } Methane production & (ml/1/50 days) & 11083.9 & 10393.0 \\
$\Sigma$ added dry volatile solid & $(\mathrm{g} \mathrm{VS})$ & 145.3 & 133.76 \\
Average methane yield & $(\mathrm{ml} / \mathrm{g} \mathrm{VS})$ & $\mathbf{7 6 . 3} \pm \mathbf{2 . 5}$ & $\mathbf{7 7 . 7} \pm \mathbf{6 . 9}$ \\
\hline
\end{tabular}

Results are indicated as average $\pm 95 \%$ confidence interval.

According to Table 5., the combined pretreatement of basic material with microwave energy and extraction did not have a significant positive or negative impact on average methane production compared to the control substrate.

The use of microwave energy can not only carry out the pretreatment of basic material, but under certain circumstances (by the simultaneous application of the microwave energy and of the solvent) an efficient and exhaustive extraction can also be carried out (microwave assisted extraction - MAE). In our earlier publications, we have reported on the possibility of MAE of valuable and utilizable polyphenolic compounds from the bark tissues of oak species (Makk et al. 2013).

According to the present results, after the extraction of polyphenolic compounds from oak bark, the remaining bark residue can be utilized for anaerobic digestion to produce methane, without the extraction hampering methane yield. Through this process, the valorization of oak bark by-product by a complex biorefinery utilization in the form of the extraction of polyphenols and subsequent biogas production using the bark residues can be accomplished in the future.

\section{CONCLUSIONS}

The present article reported on the application possibility of oak bark, as a wood industry byproduct, for the production of methane via an anaerobic fermentation process. Selected pretreatment (extraction, microwave irradiation, and the combination of both methods) were applied to the basic material in order to enhance the methane yield in the fermentation process. Only microwave pretreatment was found to effect methane yield negatively, probably due to sludge thickening or inhibitory effects. Extraction as well as combined microwave/extraction pretreatments did not influence methane yield significantly. According to the present results, oak bark can be used for anaerobic biogas production without the use of the investigated pretreatment methods. However, as shown by our earlier findings on the utilization possibilities of oak bark polyphenols extracted by microwave assisted extraction, the complex biorefinery utilization of oak bark can be accomplished in the future by microwave assisted extraction of polyphenols and subsequent biogas production using the remaining extracted bark residues. The presented processes and method could also be adapted to other forest tree species, which have not only an industrial significance as wood, but also contain bark with valuable extractives. 
Acknowledgements: This article was made in frame of the „EFOP-3.6.1-16-2016-00018 Improving the role of research+development+innovation in the higher education through institutional developments assisting intelligent specialization in Sopron and Szombathely".

\section{REFERENCES}

BROWN, D. - SHI, J. - LI, Y. (2012): Comparison of solid-state to liquid anaerobic digestion of lignocellulosic feedstocks for biogas production. Bioresource Technology 124: 379-386.

ChANDRA, R. - TAKEUCHI, H. - HASEgAWA, T. (2012): Methane production from lignocellulosic agricultural crop wastes: A review in context to second generation of biofuel production. Renewable and Sustainable Energy Reviews 16: 1462-1476.

DEUBLEIN, D. - STEINHAUSER A. (2008): Biogas from waste and renewable sources, an introduction. Weinheim: Wiley-VCH Verlag Gmbh \& Co. KGaA ISBN 978-3-527-31841-4.

Escobar, J.C. - LORA, E.S. - VENTURini, O.J. - YÁÑEZ, E.E. - CASTILlo, E.F. - AlmazAN, O. (2009): Biofuels: environment, technology and food security. Renewable and Sustainable Energy Reviews 13 (6): 1275-1287.

FENGEL, D. - WegENER, G. (1984): Wood: Chemistry, Ultrastructure, Reactions. De Gruyter, Berlin.

HENDRIKS, A.T.W.M. - ZeEMAN, G. (2009): Pretreatments to enhance the digestibility of lignocellulosic biomass. Bioresource Technology 100: 10-18.

Horn, S.J. - ESTEVEZ, M.M. - NiELSEN, H.K. - LinJORDET, R. - EIJSINK, V.G.H. (2011): Biogas production and saccharification of Salix pretreated at different steamexplosion conditions. Bioresource Technology 102: 7932-7936.

JACKOWIAK, D. - BASSARD, D. - PAUSS, A. - RIBEIRO, T. (2011): Optimisation of a microwave pretreatment of wheat straw for methane production. Bioresource Technology 102: 6750-6756.

LIEW, L.N. - SHI, J. - LI, Y. (2012): Methane production from solid-state anaerobic digestion of lignocellulosic biomass. Biomass and Bioenergy 46: 125-132.

MAKK, Á.N. - HOFMANN, T. - RÉTFALVI, T. (2013): A (+)-catechin kinyerése tölgyek kérgéböl. [Isolation of (+)-catechin from oak bark] Faipar 61 (2): 16-26. (in Hungarian)

MolnÁR, S. (2004): Faanyagismeret. [Wood Science] Szaktudás Kiadó Ház Rt., Budapest. ISBN: 9789639553170. (in Hungarian)

Monlau, F. - Sambusiti, C. - Barakat, A. - Quéméneur, M. - Trably, E. - Steyer, J.P. CARRÉRE, H. (2014): Do furanic and phenolic compounds of lignocellulosic and algae biomass hydrolyzate inhibit anaerobic mixed cultures? A comprehensive review. Biotechnology Advances 32: 934-951.

NigAM, P. - SingH A. (2011): Production of liquid biofuels from renewable resources. Progress in Energy and Combustion Science 37: 52-68.

PATIL, P.N. - GOGATE, P.R. - CSÓKA, L. - DREgElYi-Kiss, Á. - HorVATH, M. (2016): Intensification of biogas production using pretreatment based on hydrodynamic cavitation. Ultrasonic Sonochemistry 30: 79-86.

SALEHIAN, P., - KARIMI, K. (2013): Alkali pretreatment for improvement of biogas and ethanol production from different waste parts of pine tree. Industrial and Engineering Chemistry Research 52: 972-978.

SMET, E. - VAN LAngenhove, H. - DE Bo, I. (1999): The emission of volatile compounds during the aerobic and the combined anaerobic/aerobic composting of biowaste. Atmospheric Environment 33: $1295-1303$.

SONG, Z. - LiU, X. - YAN, Z. - YUAN, Y. - LiAO, Y. (2014): Comparison of seven chemical pretreatments of corn straw for improving methane yield by anaerobic digestion. PloS One 9 (4): e93801.

Sun, Y. - CHENG J. (2002): Hydrolysis of lignocellulosic materials for ethanol production: a review. Bioresource Technology 83 (1): 1-11.

TAHERZADEH, M.J. - KARIMI, K. (2008): Pretreatment of Lignocellulosic Wastes to Improve Ethanol and Biogas Production: A Review. International Journal of Molecular Science 9 (9): $1621-1651$. 
TAMÁS, J. - BLASKÓ, L. (2008): Environmental Management. University of Debrecen.

WARD, J.A. - HoBBS, P.J. - HollimAn, P.J., - JONES D. L. (2008): Optimisation of the anaerobic digestion of agricultural resources. Bioresource Technology 99: 7928-7940.

ZHAO, J. - ZHENG, Y. - LI, Y. (2014): Fungal pretreatment of yard trimmings for enhancement of methane yield from solid-state anaerobic digestion. Bioresource Technology 156: 176-181.

\section{SOURCES OF DATA}

KSH (2015): Központi Statisztikai Hivatal. [Hungarian Central Statistical Office] Budapest, Hungary. Online: https://www.ksh.hu/docs/hun/xstadat/xstadat_eves/i_ome003b.html 